\title{
Integration or Immersion? A Comparative Study at the Tertiary Level
}

\author{
La integración o la inmersión? Un estudio comparativo en el \\ nivel terciario
}

\author{
Miriam Fernandez-SAnTiago \\ University of Granada \\ (Granada, Spain)
}

\begin{abstract}
The implementation of new degrees in the Spanish university system as a result of the process of adaptation to the European Space of Higher Education (ESHE) will bring significant changes in the learning of foreign languages at this level. Different methodological approaches such as foreign linguistic immersion in the content classroom or Content and Language Integrated Learning (CLIL) might be used as a compensatory curricular strategy for the learning of foreign languages in the implementation of the new university degrees. The present article reports on research conducted at the School of Psychology of the University of Granada (Spain) where these two methodological approaches were contrasted for an assessment of their efficiency with regards to the specific learning purposes indicated above. The results obtained show the academic convenience of the implementation of CLIL methodology as a compensation strategy for the loss of courses on English for Specific Purposes at the tertiary level.
\end{abstract}

Key Words: CLIL; immersion; English; second languages; bilingual education.

\section{Resumen}

La implementación de nuevas titulaciones en el sistema universitario español como resultado del proceso de adaptación al Espacio Europeo de Educación Superior (EEES) traerá cambios significativos en el aprendizaje de lenguas extranjeras a este nivel. Diferentes enfoques metodológicos, tales como la inmersión lingüistica extranjera en el aula de contenido o el AICLE (Aprendizaje Integrado de Contenidos y Lenguas Extranjeras) podrían ser utilizados como una estrategia curricular compensatoria para el aprendizaje de lenguas extranjeras en la aplicación de nuevas titulaciones universitarias. El presente artículo describe una investigación llevada a cabo en la Escuela de Psicología de la Universidad de Granada (España), donde estos dos enfoques metodológicos fueron contrastados para la evaluación de su eficacia con respecto a los propósitos específicos de aprendizaje mencionados anteriormente. Los resultados obtenidos demuestran la conveniencia académica de la aplicación de la metodología AICLE como una estrategia de compensación para la perdida de cursos del Inglés para Fines Específicos en el nivel terciario.

Palabras Claves: AICLE; inmersión; Inglés; segundas lenguas; educación bilingüe.

\section{INTRODUCTION}

The creation of a European Higher Education Area (EHEA) as a consequence of the Bologna Accords of 1999 promotes both mobility of university students and teachers in subscribing

ACli Fernández-Santiago, M. (2011). Integration or immersion? A comparative study at the tertiary level. Latin American Joumal of Content \& Language Integrated Leaming, 4(1), 49-64. doi:10.5294/lacli1.2011.4.1.5 ISSN 2011-6721. 
European Universities, as well as the international diffusion of knowledge. In this context, the MT+2 learning objective appears as both a means and a result of the EHEA, which should consequently and necessarily increase the demand of foreign language learning at the tertiary level. Paradoxically, the restructuring of undergraduate studies into four-year degrees is reducing the foreign-language curricula of what had been formerly five-year degrees. ${ }^{1}$ Such a reduction makes it fairly complicated to achieve the objectives of mobility, plurilingualism and multiculturalism proposed by Bologna unless a methodological approach is found that might solve these apparent contradictions in accordance with the directives proposed by the EHEA for foreign language acquisition. ${ }^{2}$

The combination of content and foreign language (FL) instruction appears a feasible means for this purpose and is founded on the notion that a high exposure to the FL should improve linguistic skills in students. Still, methodologically speaking, a formula must be found to undertake the task; the options range from FL class immersion to the various modalities of Content and Language Integrated Learning (CLIL). Developing in Canada in the 1960's, the linguistic immersion model shows little exportability for the European Space of Higher Education (ESHE), since the Canadian context is not transferable to the European. In the first instance, linguistic immersion in Canada is aimed at early education; but the main impediment for exportability lies on the sociocultural context of implementation.

The complexity and diversity of the European intercultural and historical background makes methodological transferability extremely complicated. ${ }^{3}$ The $\mathrm{MT}+2$ objective is not projected at improving the intercultural coexistence of already existing bilingual communities but at promoting such coexistence among linguistically diverse cultures as part of EU policies. That is why, within the frame of tertiary education and in view of the limitations of the immersion model in certain contexts (Swain, 1988; Marsh, 2002), a methodological approach that enables the notion of a mere change in the language of instruction to be overcome is required. Previous research on higher education both in Spain (Vázquez, 2004; Barbero, 2007; Carrió, 2007; Dafouz, 2007; Frigols, 2007; Sanz-Caballero, 2007; Costa, 2009) and other countries within the EU (Wilkinson, 2004; Mellion, 2006; Foran-Storer, 2007; Airey, 2009) shows either a tendency to use linguistic immersion or CLIL modalities that consider the foreign language as a mere vehicle for instruction. Both these previous studies and my own personal experience show that when such efforts have taken place, it is usually to meet the needs of international students rather than to improve the foreign-language communicative skills of the native-student population in the academic and professional context. The institutional, economic, and academic obstacles underlying the implementation of multidisciplinarily coordinated programmes makes it difficult to pilot CLIL projects in which both content and foreign language

\footnotetext{
${ }^{1}$ Already in 2002, Kees de Bot remarked this paradoxical tendency in many European countries. Such is at least the case of the University of Granada (Spain), where most new degrees to be implemented in 2010 show a significant reduction in foreign language education. Provisional data (2010) suggests a reduction of at least a hundred credits in English as a Foreign Language.

${ }^{2}$ Wolf (2002) argues that the 1995 White-Paper political objectives proposed by the European Union for the promotion of plurilingualism will not be met if the signing member states keep reducing their language programs. Interestingly, Marsh (2002, p. 49) connects the development of CLIL to the needs resulting from the underfunded implementation of European educative policies: "Put bluntly, more students need more language competence. This is to be achieved without the opportunity for increased resources, either in time or personnel, which can be devoted to language teaching itself. Over the last decade in particular, the external pressure to find a solution appears to have led to the adoption of forms of CLIL/EMILE."

${ }^{3}$ In fact, one of the essential characteristics of CLIL methodology as compared to immersion involves adaptation to the sociocultural particularities of each national and local context (Takala, 2002).
} 
can be jointly and overtly taught, learned, and assessed; and its results compared to those obtained by the use of immersion, FL vehicular methodology.

This article presents the results of research conducted during the years 2008-2010 at the School of Psychology of the University of Granada (Spain) where two methodological approaches were contrasted for an assessment of their efficiency for the specific learning purposes presented above: namely, Class Immersion ${ }^{4}$ and Content and Language Integrated Learning. The research project was originally conceived as an attempt to compensate for the negative effects (in terms of Second Language Acquisition) resulting from the complete erasure of the subject of English for Psychologists from the new Degree on Psychology implemented in September 2010..$^{5}$ A modular CLIL approach was designed for use in the subject of Neuropsicología Cognitiva subject and compared to a class immersion approach in the already existing Cognitive Neuroscience subject. These two subjects share a common syllabus except for the fact that the latter is completely taught in English, whereas the former uses English as the language of instruction only in the practice sessions (that is, a third of the whole course in terms of credit distribution). Other differences include, in the latter course, the use of student-oriented, autonomous-learning material created to develop the students' academic reading-comprehension skills in English.

\section{METHODOLOGY}

\section{Participants}

Participants in this project include the students of the School of Psychology during the academic year of 2008-2010 who took the courses described in the following sections.

\section{Cognitive Neuroscience}

The immersion group (academic year 2009-2010) was composed of 23 students. Spaniards made only $34.78 \%$ of the total; communitarian and extracommunitarian students completed the immersion group, with $60.87 \%$ being native speakers of languages other than Spanish (Figure 1).

\footnotetext{
${ }^{4}$ I would like to distinguish "Class Immersion" from other types of linguistic immersion formats in which students are not only linguistically, but also socially immersed in the foreign-language context (either totally or partially). With the notion of (only) "class immersion," I refer to the instrucion of a content subject in a foreign language that is the mother tongue neither of students nor of the native population of the teaching social context (and most of the times, not even of teachers).

5 Despite the fact that the new Degree on Psychology specifically requires its students to acquire knowledge in a second language, the total ammount of ECTS credits dedicated to this purpose is zero (18 credits in academic year 2007-8).
} 


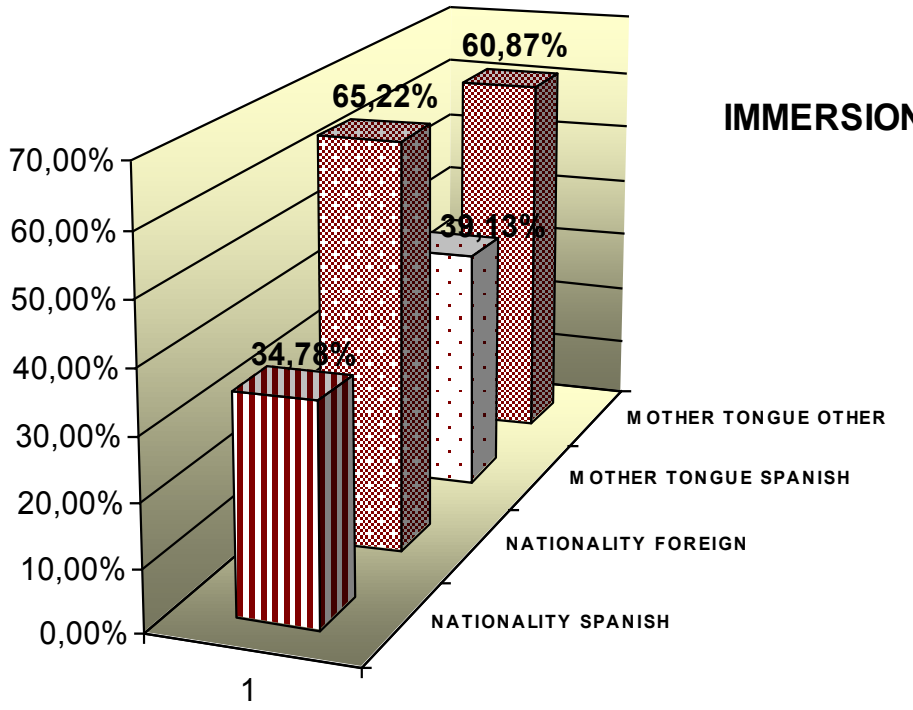

\begin{tabular}{l}
\hline I NATIONALITY SPANISH \\
O NATIONALITY FOREGN \\
$\square$ MOTHER TONGUE SPANISH \\
O MOTHER TONGUE OTHER \\
\hline
\end{tabular}

Figure 1: Immersion Group

\section{Neurociencia Cognitiva}

The CLIL group (academic year 2009-2010) included a total of 15 students, with only one nonSpanish student, which made a percentage distribution very close to the control group (Figure 2).

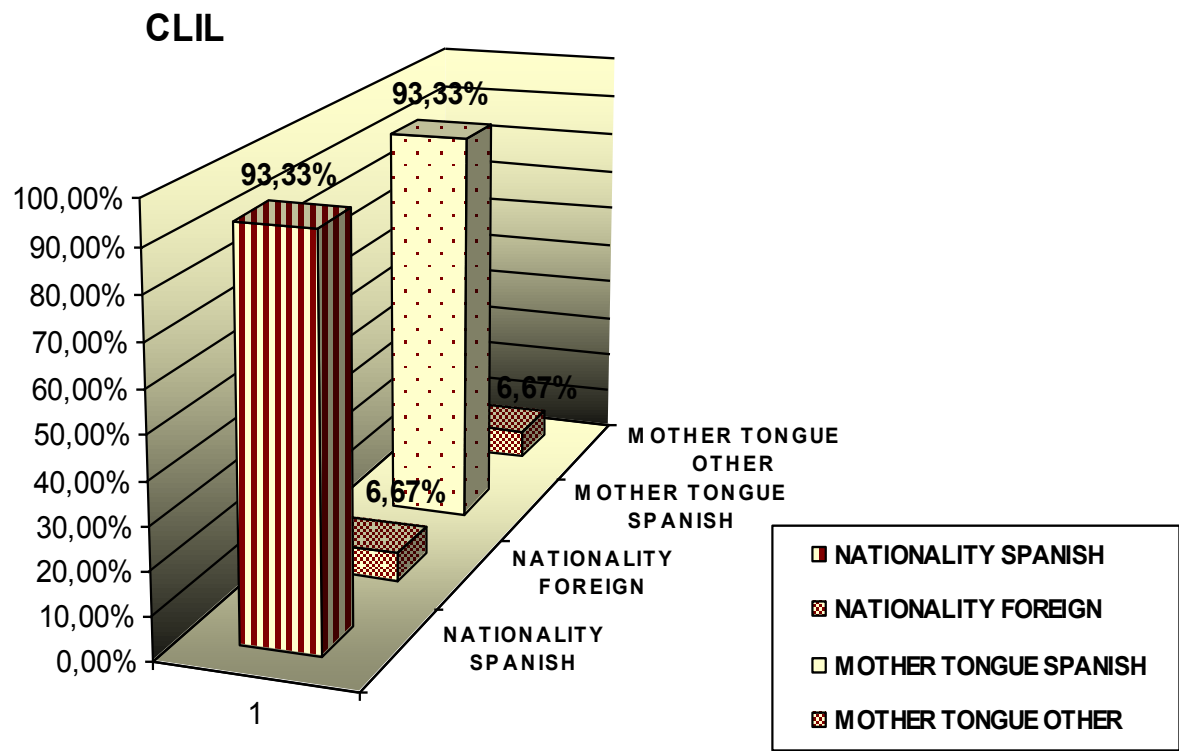

Figure 2: CLIL Group

AClî Fernández-Santiago, M. (2011). Integration or immersion? A comparative study at the tertiary level. Latin American Joumal of Content \& Language Integrated Leaming, 4(1), 49-64. doi:10.5294/lacli1.2011.4.1.5 ISSN 2011-6721. 


\section{Inglés para Psicólogos I (English for Psychologists I)}

The students who took this course participated in piloting a first version of the AcademicReading Support Materials during the academic year of 2008-2009 (64 students); they served as methodological comparative referent for the piloting of the CLIL course and as control group for the immersion course during the academic year of 2009-2010 (77 students). During the academic year of $2008-2009,89.1 \%$ of this group spoke Spanish as their mother tongue, while the remaining $10.9 \%$ spoke other languages. During the academic year of $2009-2010$, 97.4\% students were Spanish nationals and spoke Spanish as their first language, while only $2.6 \%$ were foreign students whose mother tongue was not Spanish (Figure 3).

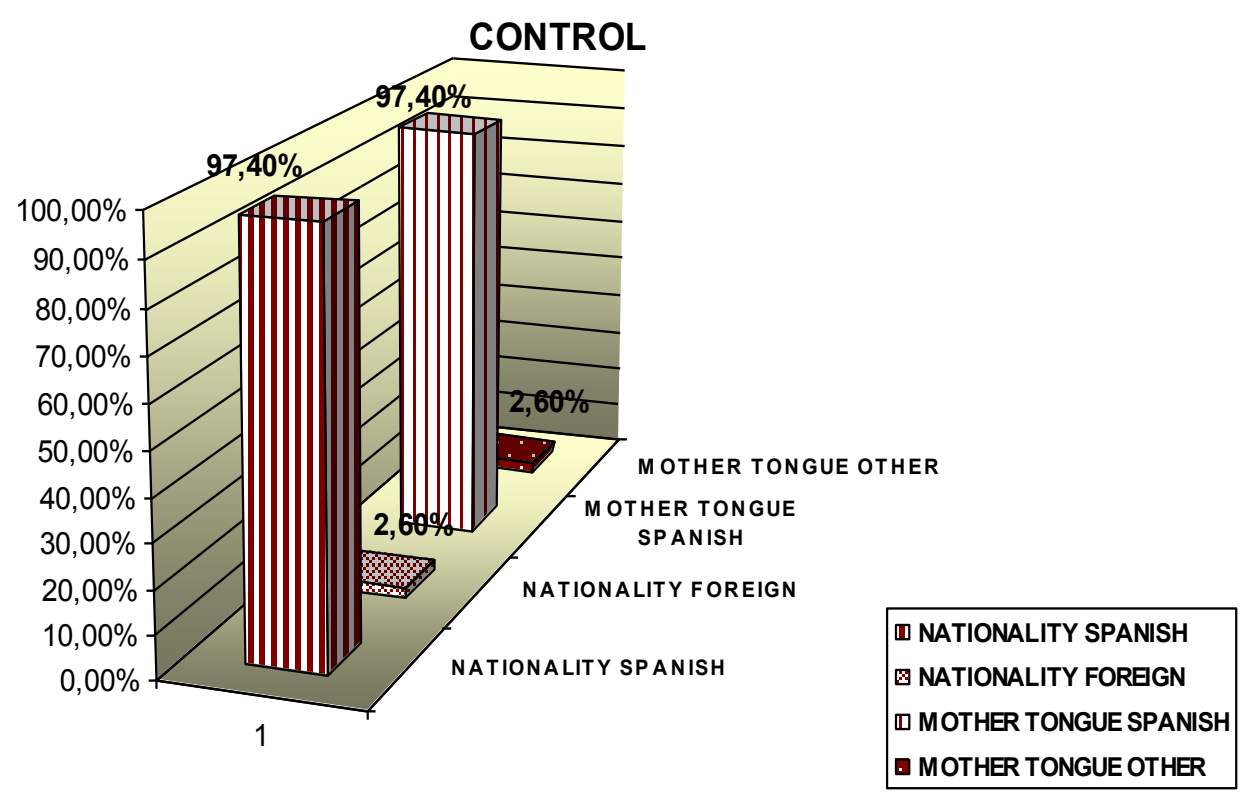

Figure 3: Control Group

Ages of participants were all in the range of 18-25 years, but since age is not a variable that affects the results obtained, this information is not included in detail.

\section{Instruments}

Several assessment questionnaires were used for this study, involving the students' initial level of English, their academic performance, and their subjective perception of their own individual learning process.

1. Initial Level of English: An extended version of the Self-Test of English ${ }^{6}$ was used, including data related to the students' linguistic competence in several languages with

\footnotetext{
${ }^{6}$ The test was developed by the English Department of Maastricht University (2002) and used as placement test at University level test for joining non-language subjects taught in English. The test consists of 99 items assessing five levels of general communicative competence in English, namely; elementary, low intermediate, intermediate, high intermediate and advanced, which roughly correspond with levels A1, A2, B1, B2 and C1 of the Common European Framework of Reference for Languages (CEFRL). This test was also used to determine the level of English of the teaching team when no other certification was available.
} 
items covering mother tongue, bilingualism, foreign languages spoken or language of instruction used for courses taken in countries other than their own.

2. Academic Evaluation: For the practice sessions, an instrument for the joint assessment of both content and overt foreign language learning was developed to match academic performance in both areas. It was intended to reveal students' should levels of acquisition for both knowledge related to Cognitive Neuroscience and communicative skills in the English language (reading comprehension, as well as both written and oral production) that allow them socialize (Soetaert, 2008) within the particular discourse of Cognitive Neuroscience in English.

3. A true/false exam on the general contents of the scientific articles used in the course was aimed at assessing reading comprehension for those articles. A Spanish version of the test was used for the CLIL group (the subject is officially taken in Spanish) and an English version for the immersion and the control groups.

4. A rubric was designed for ten-minute, oral, pair presentations of the articles included in the syllabus (one per group). It was aimed at evaluating the students' readingcomprehension of academic articles in English and their communicative skills within the academic communicative context. The instrument was intended to assess the sociability of students within the discourse of Cognitive Neuroscience in English and therefore distributed content and ESL grading in integrated dimensions that included grammar correctness and fluency (in terms of communicability), content of articles, and relation to theory (in terms of comprehension and critical reflection output). This task was performed in Spanish for the CLIL group and in English for the immersion and control groups.

Table 1: Oral Presentation Rubric

\begin{tabular}{|c|c|c|c|c|}
\hline \multirow{2}{*}{ DIMEN. } & \multicolumn{4}{|c|}{ LEVELS } \\
\hline & $0-25$ & $25-50$ & $50-75$ & $75-100$ \\
\hline 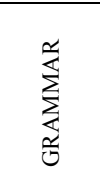 & $\begin{array}{l}\text { Uses simple grammatical } \\
\text { structures and makes simple } \\
\text { mistakes that make } \\
\text { comprehension difficult. }\end{array}$ & $\begin{array}{l}\text { Uses simple grammatical } \\
\text { structures in a correct and } \\
\text { comprehensible way. }\end{array}$ & $\begin{array}{l}\text { Uses complex grammatical } \\
\text { structures and makes mistakes } \\
\text { that do not make } \\
\text { comprehension difficult. }\end{array}$ & $\begin{array}{l}\text { Uses complex grammatical } \\
\text { structures in a correct and } \\
\text { comprehensible way. }\end{array}$ \\
\hline 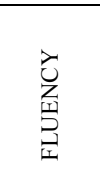 & $\begin{array}{l}\text { Heavy accent and faltering } \\
\text { flow notably preventing } \\
\text { comprehension and follow-up. } \\
\text { Totally reading from notes. }\end{array}$ & $\begin{array}{l}\text { Considerable accent and lightly } \\
\text { faltering flow making } \\
\text { comprehension and follow-up } \\
\text { moderately difficult. Totally } \\
\text { reading from notes. }\end{array}$ & $\begin{array}{l}\text { Moderate accent and lightly } \\
\text { faltering flow permitting } \\
\text { comprehension and follow-up. } \\
\text { Partially reading from notes. }\end{array}$ & $\begin{array}{l}\text { Light accent and fluent speech } \\
\text { that favour comprehension and } \\
\text { follow-up. Occasionally } \\
\text { reading from notes }\end{array}$ \\
\hline 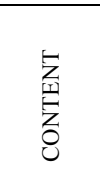 & $\begin{array}{l}\text { Lacks general perspective of } \\
\text { the main idea. Expresses } \\
\text { particular ideas in a disjointed, } \\
\text { unorganized way. } \\
\text { Occasional loss of the sense of } \\
\text { the article. }\end{array}$ & $\begin{array}{l}\text { Offers a general perspective of } \\
\text { the main idea but expresses } \\
\text { particular ideas in a disjointed, } \\
\text { unorganized and confusing } \\
\text { way. }\end{array}$ & $\begin{array}{l}\text { Offers a relatively clear vision } \\
\text { of the main idea and presents } \\
\text { contents orderly without } \\
\text { valuing their relevance and } \\
\text { contribution to the article. }\end{array}$ & $\begin{array}{l}\text { Offers a clear vision of the } \\
\text { main idea, presents contents in } \\
\text { an orderly way, and discusses } \\
\text { their relevance and } \\
\text { contribution to the article. }\end{array}$ \\
\hline 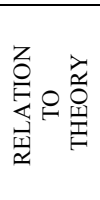 & $\begin{array}{l}\text { Does not perceive the relation } \\
\text { existing between the contents } \\
\text { of the article and the theory } \\
\text { sessions. }\end{array}$ & $\begin{array}{l}\text { Detects the essence of the } \\
\text { relation existing between the } \\
\text { contents of the article and the } \\
\text { theory sessions but is unable to } \\
\text { articulate its particularities. }\end{array}$ & $\begin{array}{l}\text { Detects the particularities of } \\
\text { the relation existing between } \\
\text { the contents of the article and } \\
\text { the theory sessions but is } \\
\text { unable to develop a personal } \\
\text { critical reflection. }\end{array}$ & $\begin{array}{l}\text { Detects the nature and } \\
\text { particularities of the relation } \\
\text { existing between the contents } \\
\text { of the article and the theory } \\
\text { sessions and proposes a } \\
\text { personal critical dialogue } \\
\text { between them. }\end{array}$ \\
\hline
\end{tabular}




\section{PROCEDURE}

The study was conducted by a multidisciplinary team of six people chosen for their expertise in the following areas: Pedagogy, CLIL, Interdisciplinary Studies, Interculturality, TESL at the tertiary level, and Cognitive Neuroscience. Four of them work at the School of Psychology of the University of Granada as teachers of one of the subjects included in the study. The other two were external collaborators from a different university who contributed in the construction of the theoretical framework and assessment of course design.

The teaching team was made up by the three professors of Cognitive Neuroscience subject and the professor of the English for Psychology subject at the School of Psychology of the University of Granada during the academic years of 2008-2010. Both the linguistic competence in English of the former (C1) and their concern for its integration in their content courses as a requisite for the inclusion of scientific texts in the syllabus met the professional interest of the later in the teaching of ESP (Psychology) as part of their teaching load. They worked collaboratively in the design and piloting of the CLIL course in comparison with the immersion and control groups. The previous existence of all participating groups as official subjects at the School of Psychology made the piloting of the CLIL course and its comparative study possible. All of them are Spanish by birth and speak Spanish as their mother tongue.

The development of the CLIL pilot involved a general design of the course and the creation of specific teaching materials. After the exhaustive analysis of existing bibliography, the joint work of the experts in AICLE and Pedagogy agreed that the design of the CLIL course should meet two basic prerequisites: firstly, the integrated learning of both Cognitive Neuroscience and English language; and also, the possibility to pilot it with the institutional, technical and human resources available. Both conditions determined that the course should have a modular structure, with a four-credit module taught in Spanish for the theoretical sessions and a two-credit module taught in English for the practice sessions. The choice of this systemproposed by Pavesi (2001) as a CLIL methodological possibility-fit the paradoxical circumstance that the Neuropsicología Cognitiva subject had to be taken in Spanish, ${ }^{7}$ although it also required the reading of scientific articles in English for its practice sessions since translations of these into Spanish were not available. The methodological options, institutional restrictions and technical means weighed, the modular course was considered to be the most feasible and least intrusive option. Thus, the whole of the 6 ECTS-credit load of the course is distributed as showed in Table 2 .

Table 2: Credit Distribution Chart

\begin{tabular}{|l|l|l|l|}
\hline Activity & Class Hours & Study Hours & Total \\
\hline Lectures (Theory) & 15 & 30 & 45 \\
\hline Academic activities (Theory) & 30 & 45 & 75 \\
\hline Practice Sessions & 15 & 40 & 55 \\
\hline Exams & 5 & & 5 \\
\hline Total & 65 & 115 & 180 \\
\hline
\end{tabular}

\footnotetext{
${ }^{7}$ The subject is officially taken in Spanish as registered in the Teaching Program of the School of Psychology.
} 
It was determined that both instruction in English and of English should occur during the practice sessions, which run parallel in time to the theory lectures. ${ }^{8}$ Theory sessions are projected as lectures and the students' reading of related texts in Spanish. Practice sessions include the students' weekly reading of non-adapted bibliographic material in English (with an approximate workload of two hours per article), ten-minute pair presentations in English and teacher-chaired discussion of articles in class alternating English and Spanish as required by mutual comprehension. A reading guide was created to support students in their autonomous, comprehensive reading of research articles in English. ${ }^{9}$ The methodology used with the immersion group was exactly the same, except for the language of instruction and the fact that autonomous reading of research articles in English was unsupported by the reading guide. The teaching materials created for the CLIL course included:

- An introduction to the textual typology of the research article composed of a presentation of the material itself that is addressed at students and aimed at providing them with a comprehensive control of their autonomous learning that contextualizes and exposes the functionality of such material within the context of both the CLIL course and their education in general.

- A presentation of the general characteristics of research articles that should help anticipate the internal structure of such texts and design a strategy for their comprehensive reading.

- Presentation of the textual conventions of the scientific writing style in relation with the characteristics and principles of the scientific method.

- Presentation of the typical organization of the research article and the textual conventions of each of its sections and subsections.

- Brief summary of the general style guidelines of the American Psychological Association (APA).

- Autonomous reading-comprehension support activities for each of the articles included in the practice syllabus. Activities are sequenced increasing in difficulty in relation both to the presentation of the activities created for each article and to the order of articles presentation in class. Thus, the reading of each article is supported by warming up activities, general and specific comprehension activities, and activities for a final reflection on the content and context of each article. Specific activities are also designed to support comprehension of the use of specific technical vocabulary in the academic context and of concrete grammatical issues that can mislead the reading of research articles in general and of the particular article in question.

- A reference guide to possible answers was created so that students can check their comprehension of each article. As recommended by Mehisto (2007) in relation to the preparation previous to the implementation of CLICL programs, all materials were tested not only in the piloting of the CLICL course and its control group during the academic year of 2009-2010, but were also pre-tested in a ESP (Psychology) course during the academic year 2008-2009. This double testing of materials allowed certain changes both in the content and format of activities to be made.

\footnotetext{
${ }^{8}$ Considering that an ECTS credit corresponds with 20-30 learning-workload hours and that the practice sessions would take two ECTS credits, the total amount of 50-60 hours adjusts to the (25+) formula proposed for CLIL modules by Marsh (2002).

${ }^{9}$ Both the reading guide and the answer key have been published under the following title: Fernández-Santiago, M., \& Tutáeva, K. (2010). Autonomous Reading Skills in Academic English. Answerkey. Granada: Comares.
} 
Electronic means were used for the coordination of trivial matters whereas periodical meetings were held with the diverse members of the team for structural and crucial methodological issues. The theoretical and practical contents and materials were entirely selected and sequenced by the coordinated work of the three professors responsible for the subjects of Neuropsicología Cognitiva and Cognitive Neuroscience. They also created the activities for academic evaluation, except for the rubric designed to evaluate oral presentations in English (integrated assessment of content and language), which required the addition of the two experts in ESL/CLIL for its design. The latter were also responsible for the elaboration of the autonomous reading support materials, which were also revised by the content experts to guarantee a correct and significant comprehension of all research articles. All evaluations were made by the professors officially responsible for each subject, which required previous meetings for reciprocal instructions aimed at the correct use of instruments when professors addressed students' skills outside their expertise (e.g. the ESL teacher received instructions to pass the true/false exam on the comprehension of general contents of the scientific articles to the control group, whereas content teachers received instructions to pass the test on the initial level of English to the immersion and CLIL groups).

\section{RESULTS}

\section{Extended Self Test of English}

The assessment of the initial level of English revealed a great disparity between the CLIL/control groups and the immersion group that could be explained by the motivation for joining the subject either in English or Spanish. The CLIL and control groups, where most students spoke Spanish as their mother tongue, had an initial B2 level of English for the 43.7\% (CLIL) and 40.5\% (control) of students, followed by level B1 for the 31\% (controls) and 25\% (CLIL), and level C1 for the $25 \%$ (CLIL) and the 19\% (control) of students. The remaining 6.3\% (CLIL) and 9.5\% (control) would have an initial level A2 of English. Thus, the only relevant difference between the CLIL and control groups would be in the distribution of the initial level of English of foreign students, which was 50\% B1 and C1 for the CLIL group (Figure 4) and 100\% B2 for the control group (Figure 5).

CLIL

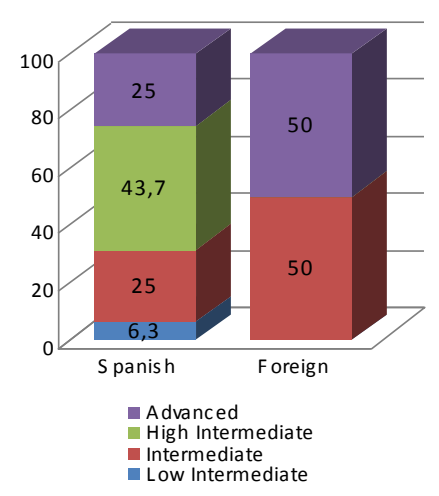

Figure 4: CLIL Group
Control

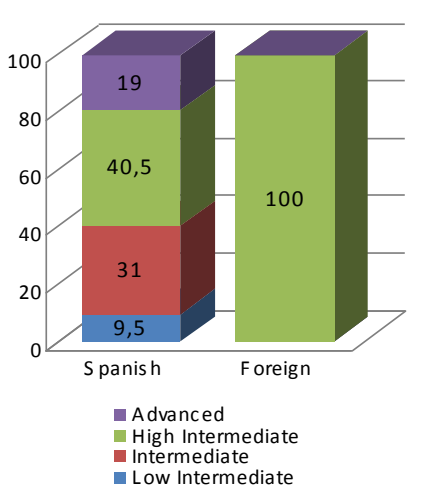

Figure 5: Control Group 
In contrast with these groups, the initial level of English of the immersion group (Figure 6) was 100\% homogeneous for Spaniards (B2), and higher for foreign students $(61.5 \%$ of foreign students had level $\mathrm{C} 1$ and $38.5 \%$ had level B2 of English).

The higher levels of English recorded for the immersion group can be the result of student's perception that their communicative skills in English would allow them to complete the subject in English. Thus, only those students who felt confident about their level of English would join the course, leading some kind of "L2 automatic segregation". Also, foreign students in the immersion group might have felt more confident in English than in Spanish, which they learn as a third language in most cases.

A comparative analysis of the initial level of

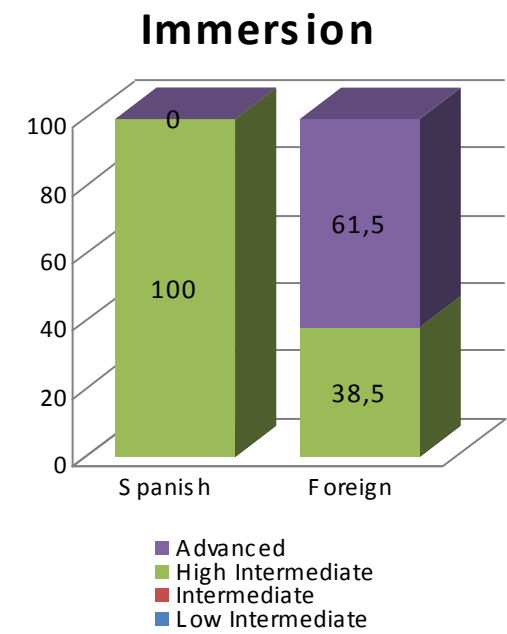

Figure 6: Immersion Group English of each group show that immersion courses do not appeal to students who want to improve their level of English, but to those who already have a high one. Students who actually felt they needed to improve their communicative skills in English (and who in fact, had a lower level of English), joined the course that was taught in Spanish probably due to an anticipatory perception of failure for the English choice. Apparently, at the tertiary level, the choice of subjects taught in a foreign language does not seem to be conditioned by the wish to learn the foreign language. When English for Specific Purposes (ESP) is a possible choice (in this case, Inglés para Psicólogos I), students prefer the traditional foreign language class rather than integrated learning. Although the course was offered as an optative course for first-year students, it was taken by students from all years of the Degree (Figure 7).

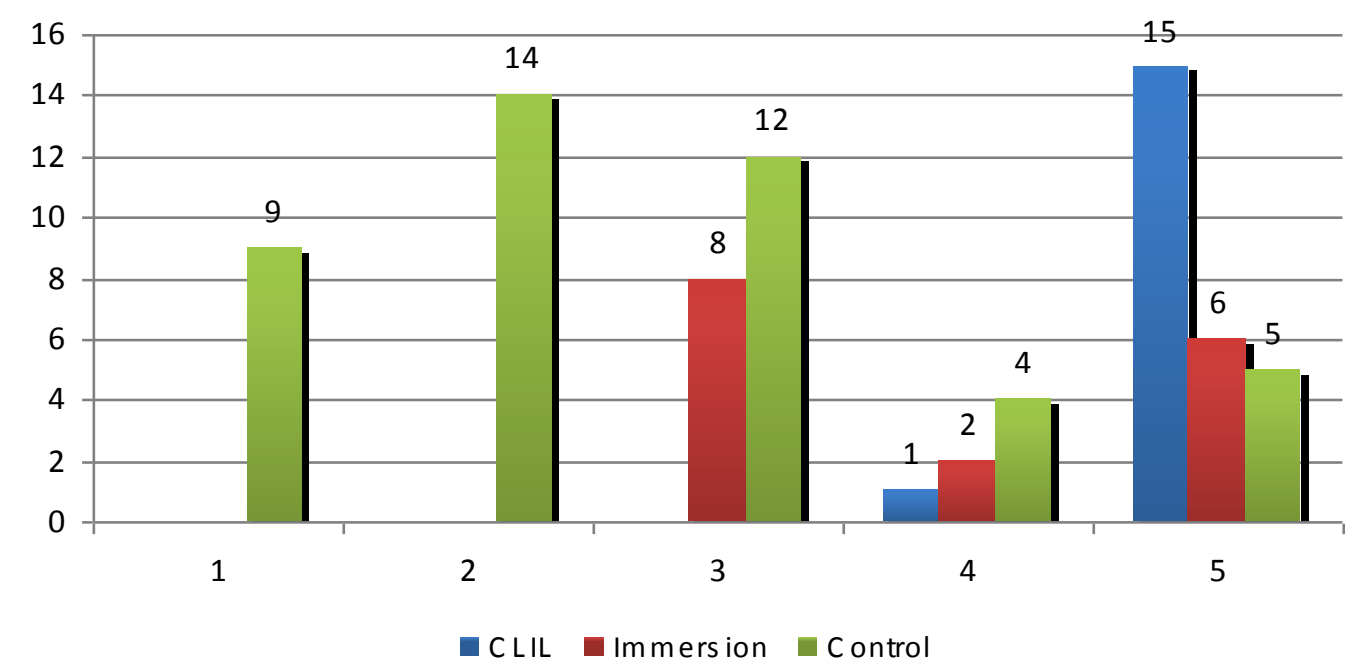

Figure 7: Course distribution of subjects

The elimination of the ESP course in the new Degree on Psychology would therefore completely eliminate the formative offer in foreign languages in the School of Psychology, although the Degree requires level B1 from students for its completion. Within this frame, CLIL subjects 
would represent a middle way between the students' formative demands and the School's resources to meet them, as it also meets the five-to-four curricular restrictions imposed by the ESHE.

\section{Academic Evaluation}

The results of the true/false exam (Figure 8) designed to assess the comprehension of the scientific articles used for the practice sessions shows the highest mean for the immersion group (5.7) and is followed by the controls (2.73) and the CLIL group (2.02). The highest mean of the immersion group corresponds with its highest initial level of English, which shows a correspondence between the level of English and content comprehension. This analysis is reinforced by the fact that in spite of not having received any instruction in cognitive neuroscience; the control group, who discussed the articles with an expert in ESP, understood the contents of research articles better than the CLIL group, who received instruction from an expert in the contents of the articles.

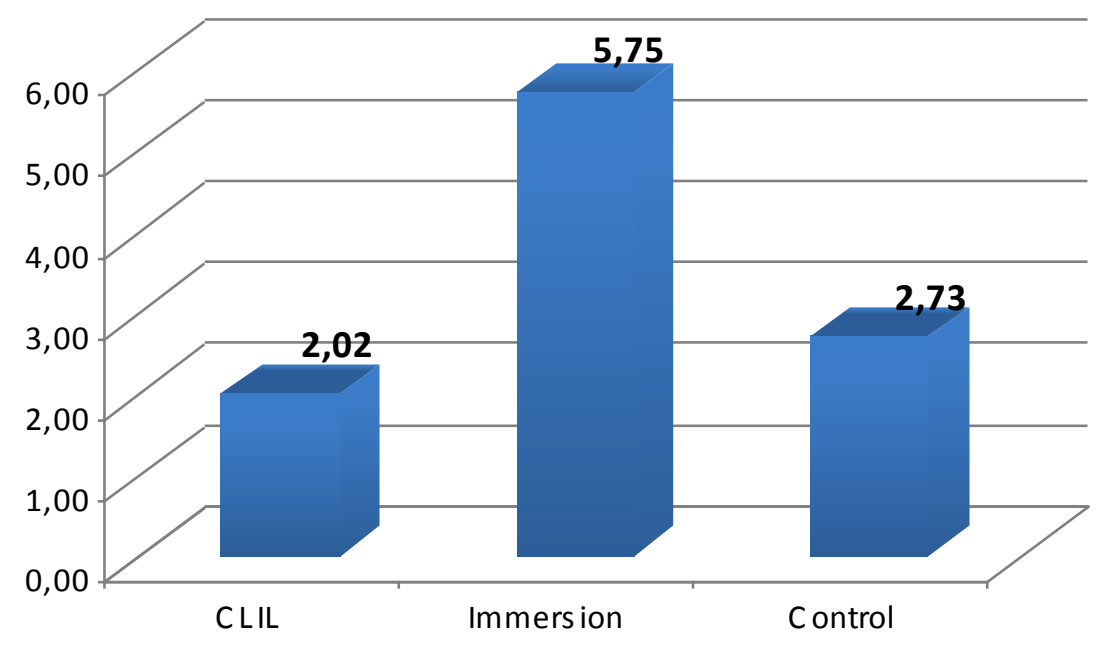

Figure 8: True/False Exam (Practice)

Although the low grades obtained by all groups show the difficulty of reading research articles in a foreign language, the results of the control group remarks the importance of Foreign Language (FL) overt instruction and the FL teacher in the CLIL classroom. Improving the reading skills of ESP students produced better results in content comprehension than theoretical instruction on such contents in their mother tongue. However, the "Content" dimension of the rubric designed for oral presentations (Figure 10) shows results for the CLIL group that suggest a correspondence between task-grading percentage and student involvement in task. Since both the oral group presentation of a single article and the written exam on the contents of twenty articles provide the same percentage of the final grade, it could be that students concentrated on tasks requiring less effort for higher results.

\section{Oral presentations}

As can be seen in Figures 9-12, results fo oral group presentations on the contents of research articles are slightly higher for the control group than for the rest, except in the dimension 
"Relation to Theory," where it shows the lowest mean (7.95); this was predictable, since the main focus for the controls was linguistic. However, the means obtained by the CLIL group in the dimensions of Grammar, Fluency, and Content were unexpectedly higher than for the immersion group, considering their respective initial levels of English. The fact that the means of the results obtained by the CLIL group in the true/false exam are lower than those obtained by the immersion group, whereas the results obtained in the oral presentations are higher, is remeniscent of the above-mentioned correspondence between effort and grading percentage. Thus, the CLIL group may have concentrated their efforts on reading some of the articles (with a special interest in the one presented in each case) with the help of the teaching materials designed for each article. The mean obtained in the dimension Relation to Theory is somewhat lower for the CLIL group, which might indicate a slight gap between the theoretical and practical sessions that could be due to a change in the language of instruction.

Grammar

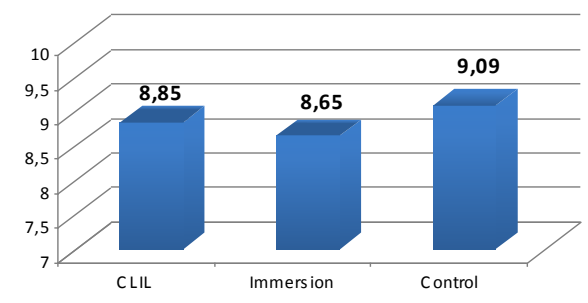

Figure 9: Group Oral Presentations (Grammar)

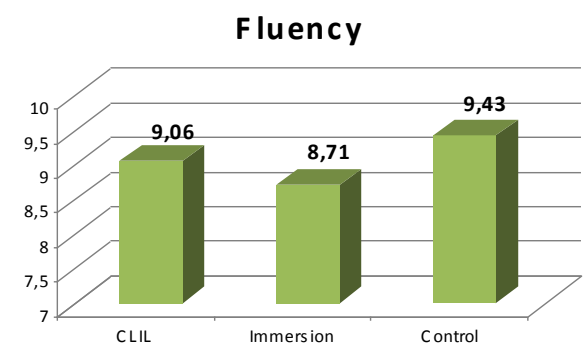

Figure 11: Group Oral Presentations (Fluency)

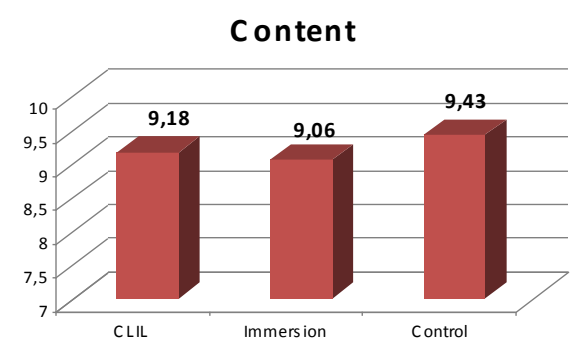

Figure 10: Group Oral Presentations (Content)

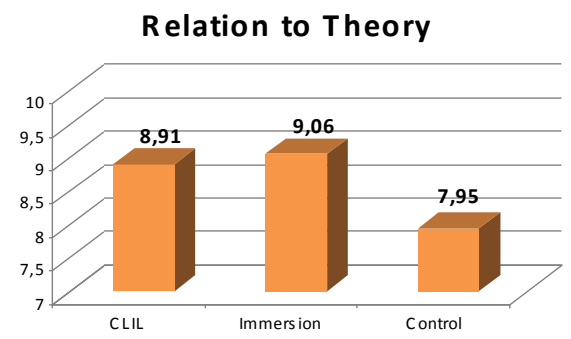

Figure 12: Group Oral Presentations (Relation to Theory)

\section{Attendance and Participation}

Attendance and participation are variables that can have some incidence on the results obtained in other tests. The means obtained for each group reflect to a large extent the percentage of final grade corresponding to this aspect. For, whereas attendance and participation made a third of the practice grade for the CLIL and immersion groups, it only made the $15 \%$ of the final grade for the control group. Thus, the two first show statistical means that range from 8 (CLIL) to 8.2 (immersion), while the control group shows a mean of 2.1 (Figure 13). 


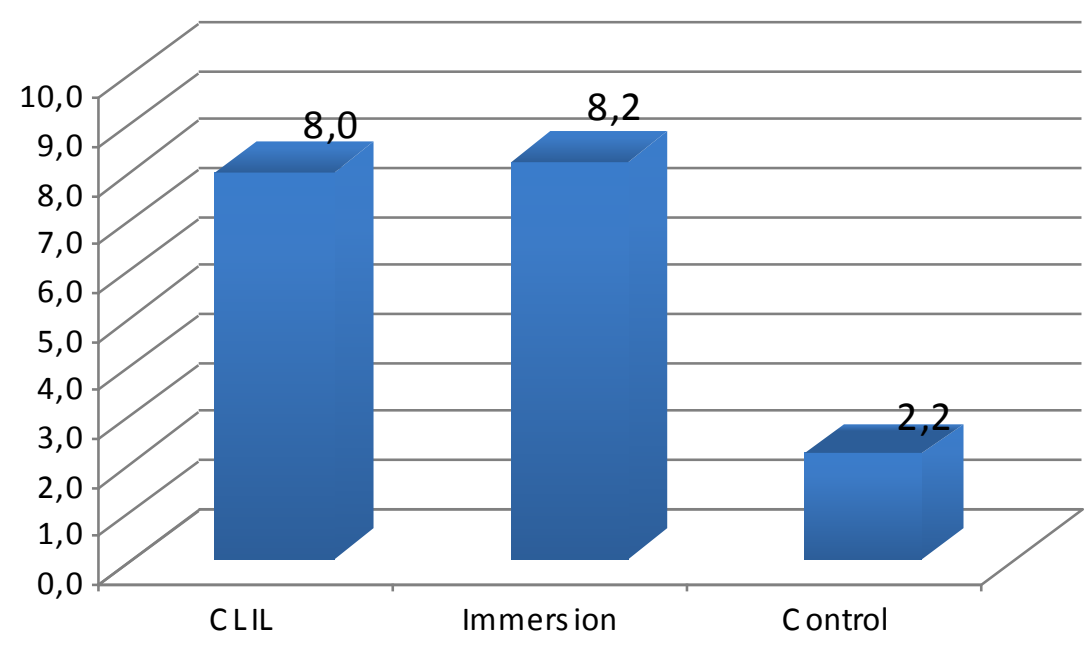

Figure 13: Attendance and Participation

These results might lead us to consider the possibility that a higher degree of autonomy in the students' learning process might results in lower class participation, but also reveals the relevance of a significant percentage of grading in encouraging the students' active participation in class. Similarly, integrated learning should also be reflected in integrated grading not only to act as a motivating force for students, but also to conduct and certify a fair evaluation of their skills acquisition.

\section{CONCLUSIONS}

Although no explicit linguistic requirement or recommendation was made to join the course of Cognitive Neuroscience (immersion), the fact that it was given in English seemed to act as some kind of matriculation level filter, leading students with lower levels of English into Neurociencia Cognitiva (CLIL) for content, and to Inglés para Psicólogos I (control) for English. The Degree in Psychology to be implemented in 2010 is designed to meet the demands of the average student that can be found in the CLIL and control groups. However, the suppression of the subject Inglés para Psicólogos I from the Degree presents the contradiction that a mere level B1 is required to enter the School whereas most of the subjects require the reading of research articles in English (level $\mathrm{C} 2$ according to the CEFR).

The high demand of instruction of ESP among the students of the School of Psychology recommends the implementation of CLIL courses in at least $50 \%$ of curriculum in order to somehow compensate the suppression of ESP courses. The impact of integrated learning at the levels of comprehension and communication of academic contents is not only remarkable in the results obtained by the CLIL control groups for the oral presentations. Even more surprising are the good results obtained by the controls in the written test on the research articles, which show that teaching materials designed to support the autonomous comprehensive reading of academic English offer similar results to those obtained by expert lecturing on the same contents. The notably low participation of the controls suggests that better results could have been obtained had a higher percentage of the final grade been assigned to participation. Similarly, assigning a proportional grading percentage to the linguistic aspects of a CLIL course might reveal the true potential of CLIL. 
In this sense, the development of CLIL at the tertiary level is to a certain extent impeded by institutional restrictions that concern FL certification of integrated learning rather than matters related to human and technical resources. Integrated certification of CLIL courses might also help to student incorporation to formative programs at the European level. At the tertiary level, it is necessary to replace the mere additional instruction in ESP to content teachers by multidisciplinary cooperation in the design of CLIL courses for the sake of academic rigor. So, not only administrative flexibility, but also professional incentives to both professors and students are required.

However, integrated certification still requires the development of a crucial methodological aspect for CLIL at the tertiary level that directly affects FLT, namely; the elaboration of a level system based on the specific FL academic skills of students. Specific training on academic reading-comprehension skills might enable student professional socialization in a foreign language. Still, this would not imply that such student has a C2 level in such foreign language, not even for the reading skill as is described by the CEFR, since such skill would be restricted to a very specific academic area and would not guarantee more basic reading skills, like for instance reading a menu in a restaurant (A2). At the tertiary level, the FL aspect of CLIL should concentrate on the communicative skills that better improve the students' socialization in each specific academic and professional context. For instance, in addition to the well-known importance of specialized technical language for all communicative skills, speaking could concentrate on the formal presentation of scientific contents for a specialized, international audience, including aspects such as respect formulae, use of deixis or connectors, that make an oral presentation clear and easy to follow. Similarly, writing could focus on the conventions ruling publication styles in international journals, the structure of research articles or the syntactic constructions that better suit a formal, objective style. Both reading and listening comprehension could involve skills related to content anticipation based on textual conventions, summarizing, skimming and scanning for specific information, or data gathering.

A general overview of the results obtained does not show any particularity that would hinder its transferability to other university degrees or languages other than English. The student's evaluation of the project reinforces the data showed by their academic evaluation in relation with the usefulness of the integrated teaching materials designed for the students' better comprehension of the contents (CLIL and control groups). Thus, the conclusion could be reached that immersion seems to suit (foreign or national) students who already have a high level in the FL of instruction better, whereas students with a lower level, such as the one required to have access to University in Spain (B1), demand overt instruction in a SL for specific purposes either as a language course or as a module integrated in a CLIL course, preferably in a simultaneous and coordinated way. It can be argued then, that when curricular five-to-four year reduction that results from the adaptation of the Spanish tertiary level to the ESHE has as a consequence the erasure of FL instruction, the use of CLIL would be a compensatory strategy to meet the formative needs of university students in a foreign language. This process would involve not only methodological, but also institutional adaptations that range from credit distribution and FL integrated certification to administrative flexibility that both enables and encourages interdisciplinary cooperation among university professors. 


\section{REFERENCES}

Airey, J. (2009). Estimating Undergraduate Bilingual Scientific Literacy in Sweden, International CLIL Research Journal, 1(2), 26-35.

Baetens Beardsmore, H. (2002). The Significance of CLIL/EMILE, in D. Marsh (ed.), CLIL/EMILE The European Dimension. Actions, Trends and Foresight Potential, (2026). Bruxelles: The European Union.

Carrió, M. \& Gimeno, A. (2007). Content and Language Integrated Learning in a technical higher education environment. In D. Mars and D. Wolff (Eds.), Diverse ContextsConverging Goals. CLIL in Europe, (pp. 103-114). Frankfurt: Peter Lang.

Costa, F. (2009). ICLHE, CLIL at the Tertiary Level of Education. State-of-the-Art. Studies About Languages (Kalbu Studijos), 15, 85-88.

Dafouz, E. (2007). On content and Language Integrated Learning in Higher Education: The Case of University Lectures, Revista Española de Linguistica Aplicada, RESLA, Special Issue 1, Dedicated to: Models and practice in CLIL, 67-82.

Dafouz, E.; Núñez, B.; Sancho, C. \& Foran, D. (2007). Integrating CLIL at the tertiary level: teachers' and students' reactions. In D. Mars and D. Wolff (Eds.), Diverse ContextsConverging Goals. CLIL in Europe, (pp. 91-102). Frankfurt: Peter Lang.

De Bot, K. (2002). CLIL in the European Context. In D. Marsh (Ed.), CLIL/EMILE The European Dimension. Actions, Trends and Foresight Potential, (pp. 29-32). Bruxelles: The European Union.

Foran-Storer, D. (2007). Teaching technical English at the tertiary and professional level: Content-based cooperative learning under the CLIL umbrella. In D. Mars and D. Wolff (Eds.), Diverse Contexts-Converging Goals. CLIL in Europe, (pp. 309-318). Frankfurt: Peter Lang.

Frigols, M.J.; Marsh, D. \& Naysmith, J. (\&). Competence-building for teachers of CLIL: Vocational education. In D. Mars and D. Wolff (eds.), Diverse Contexts-Converging Goals. CLIL in Europe, (pp. 33-46). Frankfurt: Peter Lang.

Marsh, D. (1994). Bilingual Education \& Content and Language Integrated Learning. International Association for Cross-cultural Communication, Language Teaching in the Member States of the European Union (Lingua). Paris: University of Sorbonne.

Marsh, D. (2002). CLIL/EMILE The European Dimension. Actions, Trends and Foresight Potential. Bruxelles: The European Union.

Mehisto, P. (2007). What a school needs to consider before launching a CLIL programme. In D. Mars \& D. Wolff (Eds.), Diverse Contexts-Converging Goals. CLIL in Europe, (pp. 6178). Frankfurt: Peter Lang.

Mellion, M.J. (2008). The Challenge of Changing Tongues in Business University Education. In R. Wilkinson \& V. Zegers, (Eds.), Realizing Content and Language Integration in Higher Education, (pp. 212-227). Maastricht: Universitaire Pers Maastricht.

Sanz-Caballero, S. (2007). The European space for higher education and the teaching of law: The Spanish case, European Journal of Legal Education, 4(2), 149-169.

Soetaert, R., \& Bonamie, B. (2008). New Rules for the Language \& Content Game. In CBLT/CALL to CLIL/TILL. Retrieved from http://www.euroclic.net/inhoud/bulletins/pdf/e12.pdf

Vázquez, G. (2004) La enseñanza del español con fines académicos. In J. Sánchez-Lobato \& I. Santos-Gallardo, (Eds.), Vademécum para la formación de profesores. Enseñar español como segunda lengua y lengua extranjera, (pp. 1129-1147). Madrid: SGEL. 
Wilkinson, R., (Ed.) (2004). Integrating Content and Language. Meeting the Challenge of Multilingual Higher Education. Maastricht: Universitaire Pers Maastricht.

\section{BIODATA}

Miriam Fernández-SANTIAGo is currently teaching ESL at the University of Granada (Spain). She previously taught at other universities in Spain (University of Huelva, University of Seville and University Pablo de Olavide) and the USA (Duke University). Her research interests include CLIL, Cooperative Learning, ICT, and intercultural studies. Recent titles include the volumes Guide for the Integration of ICT in the Language Class (2006), Spanish Civilization and Culture (2007), Map of Good Intercultural Practices (2009), and Autonomous Reading Skills in Academic English (2010). 